MICHAŁ ROMANOWSKI

KATARZYNA ZARZYCKA

https://doi.org/10.33995/wu2021.1.1

\title{
Pisemność oświadczenia a forma pisemna w rozumieniu art. 78 § 1 k.c. na przykładzie art. 21 ust. 4 ustawy o działalności ubezpieczeniowej i reasekuracyjnej
}

Istota problemu prawnego omawianego w niniejszym artykule sprowadza się m.in. do ustalenia na przykładzie art. 21 ust. 4 u.dz.u.r., czy ilekroć w przepisach prawa mowa jest złożeniu oświadczenia „pisemnie”, o „pisemnym oświadczeniu”, czy o „pisemnym żq̨daniu”, należy przez to rozumieć każdorazowo "formę pisemnq" czynności prawnej, o której mowa w art. 78 § 1 k.c. Stanowisko takie (nietrafne) zdaje się zajmować Komisja Nadzoru Finansowego.

Różnorodność terminologiczna i zwiqzane z niq wątpliwości co do wykładni przepisów w zakresie formy czynności prawnej powoduja problemy dla zakładów ubezpieczeń w relacjach z Komisja Nadzoru Finansowego, dla której „pisemne oświadczenie” jest tożsame z „oświadczeniem złożonym w formie pisemnej”. Stanowisko KNF nie tylko poważnie utrudnia praktykę, wpływa na koszty i bezpieczeństwo działania ubezpieczycieli, ale też nie jest uzasadnione z punktu widzenia ochrony klientów. Budzi ono zdumienie w czasach cyfryzacji, a tym bardziej COVID-19.

Jeżeli można przyjać, że do oświadczeń i żqqań, o których mowa w art. 21 ust. 4 u.dz.u.r. nie stosuje się wymogów wskazanych w art. 78 § 1 k.c., to automatycznie powstanie szersze pole do bardziej elastycznej oceny wymogów faktycznych co do takiej formy. Oznaczać to będzie, że przy zachowaniu pewnych - koniecznych z punktu widzenia celu wyżej wymienionego przepisu i ochrony klienta - wymogów technicznych co do dokumentów elektronicznych, możliwe będzie skuteczne złożenie oświadczeń w formie innej, niż tradycyjna forma pisemna (rozumiana jako złożenie własnoręcznego podpisu na papierze].

Słowa kluczowe: forma pisemna, pisemność, formy oświadczeń woli, narzędzia autoryzacyjne, dokument. 


\section{Wstęp}

W sektorze ubezpieczeniowym ustawodawca w wielu przypadkach wymaga od zakładu ubezpieczeń uzyskania pisemnego oświadczenia, pisemnego żqqania czy też inaczej sformułowanych wymogów dotyczących złożenia pisemnego oświadczenia woli. Wymóg taki wprowadza przykładowo art. 21 ust. 4 u.dz.u.r. Ustawodawca posługuje się w nim sformułowaniem pisemne oświadczenie, a nie oświadczenie złożone $w$ formie pisemnej. Zastosowana terminologia powoduje wiele problemów dotyczących rozumienia zastrzeżonej przez ustawodawcę formy czynności prawnej. Problemy te pojawiają się w szczególności w relacjach zakładu ubezpieczeń z Komisją Nadzoru Finansowego, dla której pisemne oświadczenie jest tym samym, co oświadczenie złożone w formie pisemnej.

Istota problemu prawnego omawianego w niniejszym artykule sprowadza się do ustalenia m.in., czy ilekroć w przepisach prawa mowa jest złożeniu oświadczenia pisemnie, o pisemnym oświadczeniu, czy o pisemnym żqqdaniu, należy przez to rozumieć każdorazowo „formę pisemna”" czynności prawnej, o której mowa w art. 78 § 1 k.c.

Zgodnie z brzmieniem art. 21 ust. 4 u.dz.u.r. „W przypadku gdy z analizy informacji, o których mowa w ust. 1, wynika, że potrzeby ubezpieczającego są nieadekwatne do jego doświadczenia, wiedzy w dziedzinie ubezpieczeń na życie lub sytuacji finansowej lub brak jest ubezpieczenia odpowiedniego do potrzeb ubezpieczającego, zakład ubezpieczeń przekazuje ubezpieczającemu tę informację z jednoczesnym ostrzeżeniem, że wynik analizy lub oferta zakładu ubezpieczeń uniemożliwia zaoferowanie odpowiedniego ubezpieczenia. Ubezpieczający pisemnie potwierdza otrzymanie tej informacji oraz składa pisemne oświadczenie o zapoznaniu się z ostrzeżeniem. W takim przypadku umowa ubezpieczenia może zostać zawarta tylko na podstawie pisemnego żądania ubezpieczającego".

Jeżeli bowiem można przyjąć, że do oświadczeń i żądań, o których mowa w art. 21 ust. 4 u.dz.u.r., nie stosuje się wymogów wskazanych wart. 78 § 1 k.c., to automatycznie powstanie szersze pole do bardziej elastycznej oceny wymogów faktycznych co do takiej formy. W szczególności oznaczać to będzie, że przy zachowaniu pewnych - koniecznych z punktu widzenia celu wyżej wymienionego przepisu - wymogów technicznych co do dokumentów elektronicznych możliwe będzie skuteczne złożenie oświadczeń w formie innej niż tradycyjna forma pisemna (rozumiana jako złożenie własnoręcznego podpisu na papierowym dokumencie].

\section{Funkcja i cel zastrzegania szczególnych form czynności prawnych}

Reguła polskiego prawa cywilnego jest zasada swobody formy, z której wynika możliwość dokonywania czynności prawnych w dowolnej formie. Zasada została wprowadzona w art. 60 k.c., stosownie do którego „Z zastrzeżeniem wyjątków w ustawie przewidzianych, wola osoby dokonującej czynności prawnej może być wyrażona przez każde zachowanie się tej osoby, które ujawnia jej wolę w sposób dostateczny, w tym również przez ujawnienie tej woli w postaci elektronicznej [oświadczenie woli]".

Kluczowe jest zatem samo wyrażenie oświadczenia woli na zewnątrz. Co do zasady forma tego oświadczenia jest dowolna, jeżeli ujawnia wolę w sposób dostateczny. Zasada swobody formy 
stanowi jeden z wyrazów zasady swobody umów. Jest też podyktowana względami praktycznymi: dążeniem do ułatwienia podmiotom prawa prywatnego składania oświadczeń woli ${ }^{1}$.

Od zasady swobody formy istnieja jednak wyjątki. Mogą one wynikać z zastrzeżenia szczególnej formy do dokonania określonej czynności prawnej w ustawie lub z zastrzeżenia szczególnej formy w umowie przez strony. Zastrzeżenie szczególnej formy czynności prawnej następuje przede wszystkim w celu:

1) zapewnienia autentyczności i nienaruszalności treści oświadczenia woli;

2) potwierdzenia tożsamość osoby, która składa oświadczenie woli.

Z przedstawionych celów wynika, że forma dokonania czynności prawnej stanowi swoiste narzędzie autoryzacyjne. W zależności od stopnia wymaganej autoryzacji i celu, jaki autoryzacja ma spełnić, ustawa lub strony mogą zastrzec jedną ze szczególnych form dokonania czynności prawnej, czyli jedno ze szczególnych narzędzi autoryzacyjnych.

W polskim systemie prawnym wyróżnia się następujące narzędzia autoryzacyjne (formy) dokonania czynności prawnej i powszechnie szereguje się je w kolejności od najmniej do najbardziej sformalizowanego:

1) forma dokumentowa (złożenie oświadczenia woli w postaci dokumentu, w sposób umożliwiający ustalenie osoby składającej oświadczenie) - zapewnia autentyczność i nienaruszalność treści oświadczenia woli, potwierdza tożsamość osoby, która składa oświadczenie woli;

2) zwykła forma pisemna i równorzędna jej forma elektroniczna - zapewnia autentyczność i nienaruszalność treści oświadczenia woli, potwierdza tożsamość osoby, która składa oświadczenie woli;

3) forma pisemna z datą pewną - jw., a także pozwala na stwierdzenie, że czynność prawna została dokonana najpóźniej w chwili, w której poświadczono datę;

4) forma pisemna z podpisem poświadczonym - jw. oraz ma na celu minimalizację ryzyka związanego z możliwością podważania przez daną osobę autentyczności jej podpisu;

5) akt notarialny - minimalizuje spory sądowe co do autentyczności treści złożonych oświadczeń woli oraz autentyczności podpisów; z uwagi na walor dokumentu urzędowego najpełniej realizuje funkcję dowodową.

Należy zaznaczyć, że formy dokumentowa, pisemna oraz elektroniczna mogą być zastrzeżone w ustawie pod rygorem nieważności (ad solemnitatem), dla celów dowodowych (ad probationem) lub dla wywołania szczególnych skutków prawnych (ad eventum). Zgodnie z regułą interpretacyjną wprowadzoną w art. 73 § 1 k.c. „Jeżeli ustawa zastrzega dla czynności prawnej formę pisemną, dokumentową albo elektroniczną, czynność dokonana bez zachowania zastrzeżonej formy jest nieważna tylko wtedy, gdy ustawa przewiduje rygor nieważności”. Oznacza to, że w odniesieniu do form dokumentowej, pisemnej oraz elektronicznej tylko wyraźne ustawowe zastrzeżenie pod rygorem nieważności skutkuje nieważnością czynności prawnej w razie niedochowania zastrzeżonej formy. W przeciwnym razie formę uznaje się za ustanowiona wyłącznie do celów dowodowych albo dla wywołania szczególnych skutków prawnych (jeżeli w przepisie przewidziano szczególny skutek prawny]. Wszelkie wạtpliwości w tym zakresie rozstrzyga się zgodnie z zasadą swobody wyboru formy złożenia oświadczenia woli.

1. S. Czepita, E. Drozd, Z. Kuniewicz, Z. Radwański, S. Słotwiński, [w:] System Prawa Prywatnego Tom 2. Prawo cywilne - część ogólna, [red.] Z. Radwański, Legalis 2019. Rozdział III, nb. 6. 
Jak zostało wskazane powyżej, funkcja form dokumentowej, pisemnej oraz elektronicznej jest taka sama. Zarówno forma dokumentowa, pisemna, jak i elektroniczna zapewnia autentyczność i nienaruszalność treści oświadczenia woli oraz pozwala na potwierdzenie tożsamości osoby, która składa oświadczenie woli. W konsekwencji nie można uznać, że jedna z tych form jest „lepsza” czy „silniejsza” od drugiej. Ustawodawca zrównał formę elektroniczną z pisemną (art. $78^{1}$ $\S 2$ k.c.). Jednak to samo powinno dotyczyć formy dokumentowej. W rzeczywistości forma dokumentowa jest tym samym, co forma pisemna, ponieważ użycie jednej lub drugiej formy pozwala na osiaggnięcie tego samego celu. Formy dokumentowa, pisemna i elektroniczna powinny być zatem formami równoważnymi, ponieważ stanowią równoważne narzędzia autoryzacyjne. Świadczy o tym również analogiczny skutek niedochowania formy dokumentowej, pisemnej lub elektronicznej (art. 73 § 1 k.c.).

Na marginesie warto zauważyć, że niezrozumiałe jest, dlaczego do zrównania formy elektronicznej z forma pisemną niezbędne jest opatrzenie oświadczenia woli kwalifikowanym podpisem elektronicznym. Powstaje pytanie, dlaczego w celu dochowania formy elektronicznej nie jest możliwe użycie podpisu zaufanego lub osobistego. Zgodnie z art. $78^{1} \S 1$ i 2 k.c., w przypadku użycia innego podpisu niż kwalifikowany oświadczenie nie jest uznawane za złożone w formie elektronicznej, przez co nie jest zrównane z oświadczeniem złożonym w formie pisemnej. Co innego wynika np. z k.s.h., w którym ustawodawca dopuścił możliwość dokonania tak doniosłej czynności prawnej, jakaj jest elektroniczne zawarcie umowy przy użyciu podpisu kwalifikowanego, zaufanego lub osobistego (art. $23^{1} \S 2$ k.s.h., art. $106^{1}$ k.s.h., art. $157^{1}$ k.s.h.). Na gruncie prawa spółek ustawodawca trafnie zrównał podpis zaufany i osobisty z podpisem kwalifikowanym. Ponadto, w przypadku niektórych uchwał organów spółek podejmowanych za pomocą systemu teleinformatycznego, ustawodawca wskazał wprost, że uchwały opatrzone podpisem kwalifikowanym, zaufanym lub osobistym są równoważne z uchwałami w formie pisemnej (np. art. $40^{1} \S 2$ k.s.h., $41 \S 4$ k.s.h., art. 58 § 2 k.s.h., art. $240^{1} \S 2$ k.s.h.). Nie ma żadnych przesłanek aksjologicznych, aby zasada ta nie była stosowana we wszystkich dziedzinach prawa prywatnego. Wystarczy, że spółka handlowa jest podstawową forma prowadzenia działalności gospodarczej, a w toku jej prowadzenia zapadaja miliony uchwał o doniosłym znaczeniu prawnym i ekonomicznym. Niejednokrotnie uchwały oddziałują nie tylko na stosunki wewnętrzne spółki, ale także na stosunki do jej wierzycieli, a więc szerzej - mają wpływ na bezpieczeństwo obrotu. To samo dotyczy zakładania i zmieniania umów spółek handlowych. Aktywnych spółek handlowych jest w Polsce blisko 0,5 mln. W bankowości elektronicznej i przy usługach maklerskich na wielką skalę ilościowo i wartościowo stosuje się informatyczne narzędzia (podpisy) elektroniczne, które nie muszą być kwalifikowane.

Podsumowując, należy uznać, że formy dokumentowa, pisemna i elektroniczna powinny być formami równoważnymi, ponieważ stanowią równoważne narzędzia autoryzacyjne i spełniają ten sam cel. Zarówno celem formy dokumentowej, pisemnej, jak i elektronicznej jest zapewnienie autentyczności i nienaruszalności treści oświadczenia woli oraz potwierdzenie tożsamości osoby, która składa oświadczenie woli. Ocena możliwości zastosowania narzędzi autoryzacyjnych powinna być zatem uzależniona od tego, czy ich zastosowanie pozwoli na osiagnięcie wspomnianego celu. 


\section{Pisemność oświadczenia a forma pisemna w rozumieniu art. 78 § 1 k.c.}

W pierwszej kolejności należy zauważyć, że z językowego punktu widzenia pismo nie jest utożsamiane wyłącznie z papierowym nośnikiem informacji. Pismo (rozumiane jako dokument) czy pisemność można zatem przeciwstawić ustności przekazu informacji, ale nie można go przeciwstawić nośnikom utrwalającym zapis w formie innej niż papierowa (np. elektroniczna).

Zgodnie z definicją słownikowa pismo jest to: „1. «zespół znaków graficznych będących znakami dźwięków lub pojęć; też ogół liter składających się na dany alfabet» [... 3. «wyrażanie myśli za pomocą znaków graficznych, umiejętność pisania» 4. «tekst napisany ręcznie lub maszynowo na kartce lub kartkach papieru»”. Z kolei pisać powszechnie oznacza „1. «kreślić na papierze lub innym materiale znaki graficzne ręcznie lub odbijać je za pomocą maszyny w celu wyrażenia czegoś» 2. «tworzyć coś na piśmie, zwykle dla opublikowania» 3. «formułować swoje myśli na piśmie» 4. «komunikować coś na piśmie» [...]"2.

Można zatem jasno dostrzec, że zgodnie z potocznym rozumieniem pisemności jej kluczową cecha jest utrwalenie myśli na pewnym nośniku w formie graficznej (o ile oczywiście pismo jakąkolwiek myśl zawiera). Należy też zauważyć brak nierozerwalnego związku między pismem a papierem. Pisać można nie tylko na papierze, ale także na nośniku elektronicznym czy innych, czasem (znacznie) mniej trwałych nośnikach (ścianie, szybie, czy nawet wodzie).

Co więcej, nie wymaga szerszego uzasadnienia, że we współczesnym świecie tradycyjny, papierowy nośnik informacji systematycznie traci na znaczeniu i w bardzo szybkim tempie zostaje zastępowany nośnikami elektronicznymi. Jest to okoliczność, która nie pozostaje bez znaczenia dla systemu prawa, ono zaś musi reagować na zmieniające się okoliczności. Reakcja taka może polegać:

1) na zmianie przepisów prawa (działania legislacyjne, dostosowujące odgórnie system prawa do zmieniającej się rzeczywistości] ${ }^{3}$ albo

2) na zmianie sposobu stosowania prawa (działania praktyki, w tym w szczególności orzecznictwa sądowego, które oddolnie nadają nową treść dotychczasowym przepisom, interpretując je w świetle bieżących okoliczności].

Przepis art. 21 ust. 4 u.dz.u.r. nie posługuje się w żadnym miejscu wyrażeniem $w$ formie pisemnej (jak np. art. 73 u.dz.u.r., art. 761 ? 1 k.c., art. 812 § 8 k.c.), czy też tym bardziej $w$ formie pisemnej pod rygorem nieważności (jak np. w art. 152 ust. 2 u.dz.u.r., art. $647^{1} \S 4$ k.c., art. $764^{6}$ $\S 1$ k.c.). Nie budzi wątpliwości, że - w sferze językowej - określenia pisemnie, pisemne oświadczenie, czy pisemne żqadanie są sformułowaniami odrębnymi od określenia w formie pisemnej, o którym mowa wart. 78 § 1 k.c. Jednocześnie jednym z podstawowych elementów wykładni językowej przepisu jest założenie racjonalności ustawodawcy. W ramach tego założenia przyjmuje się, że pojęciom różnym ustawa przypisuje różne znaczenia. Nie przesądza to naturalnie

2. Słownik 100 tysięcy potrzebnych słów, [red.] J. Bralczyk, PWN, Warszawa 2005, s. 559.

3. Np. możliwość zakładania niektórych spółek w formie elektronicznej przy wykorzystaniu formularzy, ochrona konsumentów przed skutkami czynności dokonywanymi w formie elektronicznej, możliwość składania formularzy podatkowych bez konieczności stosowania kwalifikowanego podpisu elektronicznego, elektroniczne sądowe postępowanie upominawcze - przykłady można w zasadzie dowolnie mnożyć, co nie oznacza, że zawsze reakcja ustawowa jest pozbawiona wad. 
w samoistny sposób, że wskazanych powyżej terminów nie należy - w ramach wykładni systemowej i funkcjonalnej - utożsamiać z formą pisemną, niemniej wymagana jest w tym zakresie pogłębiona refleksja.

W nauce prawa oraz w orzecznictwie trafnie dostrzega się wyraźne poluzowanie związku między pisemnościq a forma pisemnq w rozumieniu art. 78 § 1 k.c. Zjawisko to dotyczy nawet samego k.c., w którym stwierdzenie pismem (art. 514 k.c.) nie musi być tożsame z pisemną formą czynności prawnej ${ }^{4}$.

Tytułem przykładu innych aktów prawnych niż k.c. wskazać można k.s.h., w którym wielokrotnie pojawiają się sformułowania, które - mimo semantycznego podobieństwa - nie powinny być identyfikowane z pisemną formą czynności prawnej: w formie papierowej (art. 127 § 5, 206 $\S 1,374$ § 1 k.s.h), na piśmie (np. art. 428 § 5, 6, 7 k.s.h.), na piśmie lub w postaci elektronicznej (art. $412^{1} \S 2$ k.s.h., w którym expressis verbis podkreślono, że udzielenie pełnomocnictwa w postaci elektronicznej nie wymaga opatrzenia bezpiecznym podpisem elektronicznym weryfikowanym przy pomocy ważnego kwalifikowanego certyfikatu).

Co więcej, poluzowanie związku między pisemnościq a forma pisemnq w rozumieniu art. 78 § 1 k.c. zostało zauważone nawet w opracowaniach podręcznikowych prawa cywilnego - a zatem pozycjach, które z natury rzeczy skupiają się na recypowaniu dorobku nauki i orzecznictwa prawa, a nie na samoistnym rozwoju koncepcji naukowych. Jak trafnie zauważa się w najnowszych podręcznikach prawa cywilnego: „z problematyką swobody składania oświadczeń woli ściśle wiąże się zagadnienie pisemności. Niejednokrotnie w przepisach Kodeksu cywilnego, Kodeksu postępowania cywilnego, czy Kodeksu spółek handlowych ustawodawca używa zwrotów: pisemny, pokwitowanie, uprawdopodobniony za pomoca pisma, w piśmie, sporzqdzony na piśmie. Trudno podzielić opinię, stosownie do której pojęcia te powinny być zawsze utożsamiane z forma pisemną w rozumieniu art. 78 k.c. i kojarzone wyłącznie z wymaganiem złożenia podpisów własnoręcznych albo bezpiecznych elektronicznych. [...]

W doktrynie pojęcie pisma jest nadal błędnie kojarzone tylko z formą pisemną. [...] Wprawdzie forma pisemna (art. 78 k.c.) może być jedną z postaci sporzqdzenia na piśmie, ale nie ma uzasadnienia dla twierdzenia, że tak musi być w każdym przypadku. Kategorie pisemność, pismo zachowują nadrzędność logiczną nad formą pisemną. Użycie zwrotu pismo nie może być zatem kojarzone jedynie z formą pisemną, o której mowa w kodeksie cywilnym, albo wyłącznie z formą papierową, o której mowa w niektórych przepisach kodeksu spółek handlowych [...]. Wzorując się na nowoczesnych uregulowaniach e-commerce, należy w aktualnym stanie prawnym kategorię pismo uznać za osobny, mniej rygorystyczny niż forma pisemna sposób składania oświadczeń woli. Kategoria ta obejmuje także inne, utrwalone formy oświadczeń woli takie, jak m.in. forma dokumentowa" ${ }^{\text {. }}$.

Również w modelowych regulacjach międzynarodowych przyjmuje się coraz częściej jednolite rozumienie pisma (writing), w którym podpis utracił charakter elementu konstytutywnego,

4. Wyrok Sądu Najwyższego z 24 czerwca 2004 r., sygn. III CK 173/03, LEX; uchwała Sądu Najwyższego z 6 lipca 2005 r., sygn. III CZP 40/05, 0SNC nr 5/2006, poz. 84.

5. A. Brzozowski, W. Kocot, E. Skowrońska-Bocian, Prawo cywilne. Część ogólna, Wolters Kluwer, Warszawa 2015, s. 239. 
co pozwala uważać za pisemny każdy dokument, nawet niepodpisany ${ }^{6}$. Wskazuje się, że pismo jest dopuszczalnym środkiem ujawnienia woli i jej dostrzegalnym wyrazem, ale nie implikuje ono samo przez się formy pisemnej, ponieważ ta zależy od wymagań przewidzianych w art. 78 k.c.? Konsekwentnie: ani pismo nie powinno być utożsamiane tylko z formą pisemną z podpisem własnoręcznym, ani postać elektroniczna z formą opatrzoną bezpiecznym podpisem elektronicznym, o której mowa w art. 78 § 2 k.c. ${ }^{8}$ Kluczowe dla pojęć pisemności i pisma powinno być kryterium utrwalenia, a co za tym idzie - możliwości odtworzenia danego oświadczenia woli ${ }^{9}$.

Przedstawiony powyżej pogląd należy co do zasady uznać za trafny i stanowiący przykład reakcji nauki prawa na zmieniający się obrót prywatnoprawny. Należy jednak zastrzec, że automatyczne rozciągnięcie pisemności na formę dokumentowa w każdym przypadku jest obarczone tym samym ryzykiem, co automatyczne utożsamianie pisemności z forma pisemnq. Wydaje się, że do poszczególnych przypadków należy podchodzić w sposób zindywidualizowany, uwzględniając funkcję posłużenia się w danym przepisie wymogiem pisemności, nie narzucając z góry jednego ze sposobów wykładni. Przykładowo: trudno znaleźć logiczne uzasadnienie dla zróżnicowania wymogów co do formy zawarcia umowy o roboty budowlane między wykonawcą a podwykonawca (art. $647^{1} \S 2$ i 4 k.c., w którym wprost mowa o formie pisemnej] oraz umowy leasingu (art. $709^{2}$ k.c., w którym mowa o zawarciu umowy na piśmie pod rygorem nieważności] - abstrahując w tym miejscu od oceny trafności takiej regulacji. Ostrożnościowe podejście wymaga każdorazowej oceny, czy konkretna forma złożenia danego oświadczenia spełnia cel, dla jakiego ustawa zastrzega jakikolwiek wymóg co do tej formy.

Przykładami reakcji legislacyjnej na zmianę praktyki obrotu są m.in. reforma przepisów art. $? 7^{2}$ $78^{1}$ k.c., regulacje zawarte w ustawach szczegółowych (np. art. ? Prawa bankowego ${ }^{10} \mathrm{czy}$ art. 13 ustawy o obrocie instrumentami finansowymi ${ }^{11}$ ). Można przy tym zauważyć, że wprowadzenie formy dokumentowej do przepisów k.c. stanowi swoiste rozszerzenie dobrodziejstwa punktowego poluzowania przepisów o formie czynności prawnych zawartych w ustawach szczegółowych, na ogół obrotu prywatnoprawnego.

Zgodnie z przepisem art. $77^{2}$ k.c. do zachowania dokumentowej formy czynności prawnej wystarcza złożenie oświadczenia woli w postaci dokumentu, w sposób umożliwiający ustalenie osoby składającej oświadczenie. Z kolei zgodnie z art. $77^{3}$ k.c., dokumentem jest nośnik informacji umożliwiający zapoznanie się z jej treścią.

Jak trafnie zauważa się na gruncie art. $77^{2}-77^{3}$ k.c. „pojawiła się obok formy pisemnej nowa, uproszczona postać pisemna czynności prawnej - forma dokumentowa, będąca odpowiednikiem niemieckiej formy tekstowej (Textform, § 126b niem. k.c.). Stosownie do nowego art. $7^{2}$, do zachowania dokumentowej formy czynności prawnej wystarcza złożenie oświadczenia woli w postaci dokumentu, w sposób umożliwiający ustalenie osoby składającej oświadczenie. Forma

6. M. Giaro, Cywilnoprawne pojęcie pisemności w społeczeństwie informacyjnym, „Państwo i Prawo” 2009, nr10, s. 35.

7. Tak ibidem, s. 40.

8. W. Kocot, Korzystanie z sieci teleinformatycznych w stosunkach korporacyjnych spółek akcyjnych, „Przegląd Prawa Handlowego" 2011, nr 2, s. 5.

9. Por. ibidem, s. 6-7; M. Giaro, op. cit., s. 37.

10. Tekst jedn. Dz. U. 2015, poz. 128.

11. Tekst jedn. Dz. U. 2014, poz. 94. 
dokumentowa nie jest, tak jak forma elektroniczna, ekwiwalentem formy pisemnej. Różni się od niej przede wszystkim brakiem wymagania złożenia na dokumencie własnoręcznego podpisu. W tak zaproponowanym ujęciu wymagania formy dokumentowej spełni nie tylko dokument w postaci tekstowej, w postaci audialnej, lub audiowizualnej z podpisem powielanym mechanicznie (np. facsimile, kopia faksowa, zeskanowana), lecz także wiadomość elektroniczna (mailowa) zakończona wpisem imienia i nazwiska składającego lub danymi pozwalającymi ustalić jego tożsamość. Warunkiem bezwzględnym jest możliwość indywidualizacji składającego oświadczenie"12.

Wprowadzenie art. $? ?^{2}-77^{3}$ k.c. było uzasadnione wobec znacznego rozwoju technologii służących do zapisywania i utrwalania danych. Współcześnie rodzi to konieczność odejścia od tradycyjnego rozumienia dokumentu wyłącznie jako informacji utrwalonej za pomoca pisma na nośniku materialnym. Szerokie ujęcie dokumentu (zbliżenie do trwałego nośnika informacji) definiuje to pojęcie przy zastosowaniu kryterium przedmiotowo-funkcjonalnego. Chodzi tu o nawiązanie do ujęcia dokumentu jako przekazu woli ludzkiej, co bazuje na etymologii słowa documentum, stanowiacego połączenie łacińskich do, dare - dawać, przekazywać i mens, mentis - oznaczających wolę.

Konstytutywna cechą dokumentu jest jego intelektualna zawartość - treść obejmująca różnego rodzaju oświadczenia, w tym oświadczenia woli. Jednocześnie nowa definicja dokumentu jest technologicznie neutralna. Treść dokumentu może zostać dowolnie ujawniona (znaki graficzne, dźwięk, obraz), a także utrwalona na dowolnym nośniku (papier, urządzenie informatyczne) i przy pomocy dowolnych środków (pióro, komputer, telefon komórkowy). Granicę tej neutralności wyznacza jednak realizowana przez dokument funkcja dowodowa, która wymaga, aby sposób utrwalenia informacji umożliwiał jej zachowanie i odtworzenie. Te cechy dokumentu odnoszą się w równym stopniu zarówno do dokumentów sporządzonych w sposób tradycyjny, jak i do dokumentów elektronicznych.

Taki sposób zdefiniowania dokumentu nawiązuje do najnowszych trendów prawodawstwa europejskiego. W przyjętym projekcie Common Frame of Reference (CFR) pojęcie pisma odwołuje się do współczesnych osiagnięć w dziedzinie utrwalania i przekazywania informacji, odbiegając przy tym dość zdecydowanie od zwykłego rozumienia tego terminu. Według CFR pismo (writing) oznacza każdy sposób komunikacji i utrwalania oświadczeń lub informacji, który zapewnia ich zachowanie w formie materialnej lub kształcie, który da się odtwarzać w postaci materialnej.

Wskazana powyżej zmiana ma w założeniu służyć ogólnemu trendowi odformalizowania obrotu prawnego i zmniejszenia kosztów obrotu. Jest to także wyraz realizowania idei społeczeństwa cyfrowego. Należy zaznaczyć, że elektroniczna forma komunikacji ułatwia także funkcje dowodowe, kontrolne, przechowywanie korespondencji i sprzyja ochronie środowiska.

Nie można zatem z góry przyjąć, że forma tradycyjna (papierowa) jest formą „lepsza” od innych, dokumentowych nośników informacji. Wręcz przeciwnie, wraz z rozwojem technologii oraz wpływem tego rozwoju na stosunku społeczne i gospodarcze uwidaczniają się przewagi elektronicznych form przekazywania i przechowywania dokumentów względem tradycyjnych form papierowych.

Dokumenty w formie elektronicznej zapewniają co najmniej równoważny, jeżeli nie łatwiejszy, dostęp do zawartych w nich informacji w porównaniu z formą papierową. Przykładowo, aby przekazać dokument papierowy na odległość, konieczne jest jego wysłanie, najczęściej poczta. Z jednej strony list jest narażony na przypadkową utratę przez pośrednika (firmę pocztową,

12. A. Brzozowski, W. Kocot, E. Skowrońska-Bocian, op. cit., s. 241-242. 
kurierską), z drugiej zaś - adresat nie ma gwarancji, że list w wygodny i przystępny sposób zostanie mu dostarczony.

Na marginesie można zwrócić uwagę, że forma papierowa nie zapewnia także gwarancji powiązania danej osoby z treścią dokumentu (podpis może zostać złożony na ostatniej stronie, a treść wcześniejszych stron może zostać łatwo podmieniona). Co więcej, forma papierowa nie przesądza również o 100\% pewności, że oświadczenie pochodzi od danej osoby. Dotyczy to zarówno zwykłej formy pisemnej, kiedy podpis nie jest składany w obecności przedstawiciela drugiej strony, jak i form kwalifikowanych (np. aktu notarialnego), kiedy to osoba składająca oświadczenie może podszywać się pod inną osobę, korzystając ze sfałszowanego czy skradzionego dokumentu tożsamości. Na marginesie można dodać, że także w przypadku bezpiecznego podpisu elektronicznego, weryfikowanego za pomocą ważnego, kwalifikowanego certyfikatu, brak 100\% pewności co do tożsamości osoby autoryzującej dokument (ryzyko utraty instrumentów do autoryzacji jest zbliżone do ryzyka utraty innego dokumentu potwierdzającego tożsamość].

Z punktu widzenia prawa cywilnego kluczowe znaczenie ma zatem wymaganie poziomu pewności (wiarygodności) odpowiedniego do danych okoliczności, które wpływa na dobór odpowiedniego narzędzia autoryzacyjnego (odpowiedniej formy). Innej pewności wymaga zakup nieruchomości, a innej - zakup środków spożywczych czy zawarcie umowy ubezpieczenia. Dotyczy to zarówno formy tradycyjnej, papierowej dokumentów, jak i formy elektronicznej.

Podsumowując powyższe wnioski, należy uznać, iż istnieją silne argumenty przemawiające za tym, że wraz z rozwojem techniki, stosunków społecznych oraz praktyki obrotu prywatnoprawnego, automatyczne utożsamianie pisemności (np. w związku z posługiwaniem się przez ustawę sformułowaniami pisemnie, pisemne oświadczenie czy pisemne żqdanie] z forma pisemnq $z$ art. 78 § 1 k.c. jest błędne. Pisemność - także od strony czysto językowej - jest bowiem pojęciem szerszym od definicji formy pisemnej z art. 78 § 1 k.c. W konsekwencji: pisemność zastrzeżona w art. 21 ust. 4 u.dz.u.r. nie oznacza formy pisemnej, o której mowa w art. 78 § 1 k.c.

Rozerwanie związku między forma pisemnq a pisemnościq pozwala na bardziej elastyczne podejście do rygorów formy składania oświadczeń wymaganych przez dane przepisy prawa. Podstawową różnicą pozwalającą na większą efektywność obrotu jest pozbawienie pisma wymogu własnoręcznego podpisania, o którym mowa w art. 78 § 1 k.c. Kolejną różnica jest oderwanie pisma od papierowego nośnika informacji - abstrahując w tym miejscu od oceny, czy forma pisemna, o której mowa w art. 78 § 1 k.c., w ogóle wymaga tego, aby nośnikiem informacji był papier.

Oświadczenie złożone pisemnie, powinno zapewniać spełnienie następujących cech:

1) trwałość nośnika, na którym zapisano oświadczenie (gwarancja odtwarzalności oświadczenia w przyszłości bez możliwości edycji lub zniekształcenia treści);

2) identyfikowalność (w rozsądnym zakresie) osoby składającej oświadczenie;

3) trwałość powiązania danych identyfikujących osobę składającą oświadczenie z treścią zapisaną na nośniku informacji.

Wykorzystanie wyżej wymienionych cech pozwala na spełnienie wymogów pisemności, o których mowa w art. 21 ust. 4 u.dz.u.r., także z uwagi na cel przepisu.

Celem przepisu art. 21 ust. 4 u.dz.u.r. jest ochrona klienta zakładu ubezpieczeń (ubezpieczającego lub ubezpieczonego - w zależności od sytuacji] przed nieświadomym narażeniem się na ryzyko inwestycyjne, jakie wiązać się może z inwestycją w skomplikowany ubezpieczeniowy produkt inwestycyjny, którym mogą być ubezpieczeniowe fundusze kapitałowe, dostępne w ramach umowy ubezpieczenia na życie z ubezpieczeniowym funduszem kapitałowym. 
Przewidzianym przez ustawodawcę sposobem ochrony klienta są obowiązki nakładane na zakłady ubezpieczeń. Zakład ubezpieczeń zobowiązany jest do zebrania informacji o potrzebach klienta, jego wiedzy i doświadczeniu w dziedzinie ubezpieczeń na życie oraz jego sytuacji finansowej. Zebrane informacje powinny zostać wykorzystane do zaproponowania klientowi umowy adekwatnej do jego potrzeb. Umowa nieodpowiadająca potrzebom klienta - w tym wiążąca się z ryzykiem wyższym niż akceptowane zgodnie z wynikami ankiety - może zostać zawarta jedynie na pisemne żądanie klienta (art. 21 ust. 4 u.dz.u.r., a w przypadku umów zawieranych na cudzy rachunek - art. 21 ust. 4 w zw. z ust. 5 u.dz.u.r.).

Z punktu widzenia celu przepisu art. 21 ust. 4 u.dz.u.r. wystarczające jest zatem, aby nie budziło (rozsądnych) wạtpliwości, że oświadczenie lub żądanie, o którym mowa w przepisie, pochodzi od klienta, a klient został odpowiednio poinformowany o ryzyku. Istotne znaczenie będzie tu mieć kwestia dowodowa. Chodzi zatem o to, aby ubezpieczyciel mógł w rozsądnym zakresie wykazać, iż ubezpieczający zapoznał się z informacjami przedstawionymi przez ubezpieczyciela oraz że złożył stosowne oświadczenie i żądanie. Konieczne jest także zapewnienie, aby dokument sygnowany przez klienta nie mógł ulec późniejszemu przetworzeniu. Jak zostało już wykazane, ze względu na rozwój technologiczny osiągnięcie tego celu jest łatwiejsze przy wykorzystaniu narzędzi informatycznych niż w przypadku kartki papieru, której archiwizacja bywa zawodna.

W związku z powyższym, dokonując oceny narzędzi autoryzacyjnych, które moga zostać zaproponowane przez zakład ubezpieczeń, przykładowo takich jak:

1) potwierdzenie oświadczenia przez wpisanie nr PIN otrzymanego SMS-em lub

2) wzmocniony podpis cyfrowy,

należy uznać, że w przypadku ich zastosowania cel art. 21 ust. 4 u.dz.u.r. będzie zrealizowany w znacznie wyższym stopniu niż w przypadku tradycyjnego rozwiązania, jakim jest kartka papieru. Powyższe rozwiązania są również bardziej efektywne z ekonomicznego punktu widzenia, ponieważ z uwagi na skalę działalności zakładów ubezpieczeń pozwolą na zminimalizowanie kosztów związanych z papierowymi oświadczeniami (koszty wysyłki, papieru, archiwizacji itp.).

Przedstawione powyżej przykładowe narzędzia autoryzacyjne niewątpliwie spełniaja cechy: 1) trwałości nośnika, na którym zapisano oświadczenie (gwarancja odtwarzalności oświadczenia w przyszłości bez możliwości edycji lub zniekształcenia treści];

2) identyfikowalności (w rozsądnym zakresie) osoby składającej oświadczenie;

3) trwałości powiązania danych identyfikujących osobę składającą oświadczenie z treścią zapisaną na nośniku informacji,

dzięki czemu spełniają wymogi pisemności, o których mowa w art. 21 ust. 4 u.dz.u.r.

\section{Podsumowanie}

Reguła polskiego prawa cywilnego jest zasada swobody formy, z której wynika możliwość dokonywania czynności prawnych w dowolnej formie. Od zasady tej istnieja jednak wyjatki. Forma dokonania czynności prawnej stanowi swoiste narzędzie autoryzacyjne. W zależności od stopnia wymaganej autoryzacji i celu, jaki autoryzacja ma spełnić, ustawa lub strony moga zastrzec jedną ze szczególnych form dokonania czynności prawnej, czyli jedno ze szczególnych narzędzi autoryzacyjnych. 
Formy dokumentowa, pisemna i elektroniczna stanowią równoważne narzędzia autoryzacyjne i spełniają ten sam cel, dlatego też powinny być formami równoważnymi. Zarówno celem formy dokumentowej, pisemnej, jak i elektronicznej jest zapewnienie autentyczności i nienaruszalności treści oświadczenia woli oraz potwierdzenie tożsamości osoby, która składa oświadczenie woli. Ocena możliwości zastosowania narzędzi autoryzacyjnych powinna być zatem uzależniona od tego, czy ich zastosowanie pozwoli na osiaggnięcie wspomnianego celu.

Przepis art. 21 ust. 4 u.dz.u.r. nie posługuje się w żadnym miejscu sformułowaniem $w$ formie pisemnej, czy też tym bardziej w formie pisemnej pod rygorem nieważności. Nie budzi wạtpliwości, że - w sferze językowej - terminy pisemnie, pisemne oświadczenie, czy pisemne żqdanie są określeniami odrębnymi od terminu w formie pisemnej, o którym mowa w art. 78 § 1 k.c. W nauce prawa oraz w orzecznictwie trafnie dostrzega się wyraźne poluzowanie związku między pisemnościq a forma pisemnq w rozumieniu art. 78 § 1 k.c.

Pismo nie jest utożsamiane wyłącznie z papierowym nośnikiem informacji. Kluczowe dla pojęć pisemności i pisma powinno być kryterium utrwalenia, a co za tym idzie - możliwości odtworzenia danego oświadczenia woli. Oświadczenie złożone pisemnie powinno zapewniać spełnienie następujacych cech: 1) trwałość nośnika, na którym zapisano oświadczenie (gwarancja odtwarzalności oświadczenia w przyszłości bez możliwości edycji lub zniekształcenia treści);

2) identyfikowalność (w rozsądnym zakresie) osoby składającej oświadczenie;

3) trwałość powiązania danych identyfikacyjnych osobę składającą oświadczenie z treścią zapisaną na nośniku informacji.

Celem art. 21 ust. 4 u.dz.u.r. jest ochrona klienta zakładu ubezpieczeń (ubezpieczającego lub ubezpieczonego - w zależności od sytuacji] przed nieświadomym narażeniem się na ryzyko inwestycyjne, jakie wiązać się może z inwestycją w złożony ubezpieczeniowy produkt inwestycyjny, jakim mogạ być ubezpieczeniowe fundusze kapitałowe.

Z punktu widzenia celu przepisu art. 21 ust. 4 u.dz.u.r. wystarczające jest, aby nie budziło (rozsąnych) watpliwości, że oświadczenie lub żądanie, o którym mowa w przepisie, pochodzi od klienta, a klient został odpowiednio poinformowany o ryzyku inwestycyjnym. Kluczowe znaczenie ma tu kwestia dowodowa. Powtórzmy zatem: pisemność zastrzeżona w art. 21 ust. 4 u.dz.u.r. nie oznacza formy pisemnej, o której mowa w art. 78 § 1 k.c., ponieważ cel art. 21 ust. 4 u.dz.u.r. nie wskazuje na konieczność zastosowania szczególnej formy i nie została ona wyraźnie zastrzeżona przez ustawodawcę.

\section{Wykaz źródeł}

Brzozowski A., Kocot W., Skowrońska-Bocian E., Prawo cywilne. Część ogólna, Wolters Kluwer, Warszawa 2015.

Czepita S., Drozd E., Kuniewicz Z., Radwański Z., Słotwiński S., [w:] System Prawa Prywatnego Tom 2. Prawo cywilne - część ogólna, Radwański Z. [red.], Legalis 2019.

Giaro M., Cywilnoprawne pojęcie pisemności w społeczeństwie informacyjnym, „Państwo i Prawo” 2009, nr 10.

Kocot W., Korzystanie z sieci teleinformatycznych w stosunkach korporacyjnych spółek akcyjnych, „Przegląd Prawa Handlowego" 2011, nr 2.

Słownik 100 tysięcy potrzebnych słów, Bralczyk J. [red.], PWN, Warszawa 2005. 


\section{The written form of the statement versus the written form within the meaning of Article $78 \S 1$ of the Civil Code based on the example of Article 21 [4] of the Insurance and Reinsurance Act}

The essence of the legal problem discussed in this article boils down to determining, on the example of Article 21 (4) of the u.dz.u.r., inter alia, whether each time the law refers to making a statement "in writing", a "written declaration" or a "written request" it should always be understood as a "written form" of a legal action referred to in Article $78 \S 1$ of the Civil Code. This (incorrect) position seems to be taken by the Financial Supervision Commission.

The diversity of terminology and the related doubts about the interpretation of the provisions regarding the form of a legal action cause problems for insurance companies in their relations with the Financial Supervision Authority, for which a "written statement" is the same as a "statement made in written form". The FSC's position seriously obstructs the practice, cost and safety of insurers, and is not supported by customer protection. It is astonishing in the digital age, let alone COVID-19.

If it can be assumed that the requirements indicated in Article $78 \S 1$ of the Civil Code do not apply to the statements and demands referred to in Article 21 (4) of the u.dz.u.r., then automatically there will be a wider field for a more flexible assessment of the factual requirements for such a form. This will mean that while maintaining certain - necessary from the point of view of the purpose of the abovementioned provision and customer protection - technical requirements as to electronic documents, it will be possible to effectively make statements in a form other than the traditional written form (understood as putting a handwritten signature on paper].

Key words: written form, writtenness, forms of declarations of intent, authorization tools, document.

PROF. DR HAB. MICHAŁ ROMANOWSKI - Instytut Prawa Cywilnego, Wydział Prawa i Administracji Uniwersytetu Warszawskiego; w latach 2006-2015 (do chwili likwidacji) członek Komisji Kodyfikacyjnej Prawa Cywilnego, przewodniczący zespołu ds. umowy ubezpieczenia; wspólnik w kancelarii Romanowski i Wspólnicy.

email: m.romanowski@romanowski.eu

ORCID: 0000-0003-1065-0958

KATARZYNA ZARZYCKA - aplikantka adwokacka w kancelarii Romanowski i Wspólnicy, laureatka ogólnopolskiego konkursu Przeglądu Prawa Handlowego na najlepsze prace magisterskie z prawa handlowego za pracę pt. Corporate governance oczami Warrena Buffeta napisaną na Wydziale Prawa i Administracji Uniwersytetu Warszawskiego pod kierunkiem prof. Michała Romanowskiego. email:k.zarzycka@romanowski.eu

ORCID: 0000-0003-4726-3214 